(c) American Dairy Science Association, 2004.

\title{
Impact of Autolytic, Proteolytic, and Nisin-Producing Adjunct Cultures on Biochemical and Textural Properties of Cheddar Cheese
}

\author{
L. Sallami, ${ }^{1}$ E. E. Kheadr, ${ }^{1,2}$ I. Fliss, ${ }^{1}$ and J. C. Vuillemard ${ }^{1}$ \\ ${ }^{1}$ Centre de Recherche en Sciences et Technologie du Lait (STELA), \\ Université Laval, Québec, PQ, Canada, G1K 7P4 \\ ${ }^{2}$ Department of Dairy Science and Technology, Faculty of Agriculture, \\ University of Alexandria, Alexandria, Egypt
}

\begin{abstract}
The effect of incorporating a highly autolytic strain (Lactobacillus delbrueckii subsp. bulgaricus UL12) a proteolytic strain (Lactobacillus casei subsp. casei L2A), or a nisin Z-producing strain (Lactococcus lactis, subsp. lactis biovar diacetylactis UL719) into Cheddar cheese starter culture (Lactococcus lactis $\mathrm{KB}$ and Lactococcus cremoris $\mathrm{KB}$ ) on physicochemical and rheological properties of the resultant cheeses was examined. Cheeses were ripened at $7^{\circ} \mathrm{C}$ and analyzed over a 6 -mo period for viable lactococcal and lactobacilli counts, $\mathrm{pH}$, titratable acidity (TA), lipolysis, proteolysis, and textural characteristics. The combination of the nisin-producing strain and autolytic adjuncts significantly increased the production of water-soluble nitrogen, free amino acids, and free fatty acids. The effect of Lc. diacetylactis UL719 alone or of $L b$. casei L2A on water-soluble nitrogen and free amino acid contents were also significant, whereas their effect on free fatty acids was not. Viable counts of $L b$. bulgaricus UL12 were significantly reduced in the presence of Lc. diacetylactis UL719. Lactobacillicontaining cheeses showed significantly lower values for hardness, fracturability, and springiness. It could be concluded that the addition of $L b$. bulgaricus UL12 together with a nisin-producing strain produces a greater increase in cheese proteolysis and an improvement in Cheddar cheese texture.
\end{abstract}

(Key words: Cheddar ripening, Lactobacillus delbrueckii subsp. bulgaricus, nisin Z, proteolytic activity)

Abbreviation key: AU = arbitrary unit, IU = international unit, MRS = de Man, Rogosa, and Sharpe, NSLAB = nonstarter lactic acid bacteria, RSM = reconstituted skim milk, $\mathbf{T A}=$ titratable acidity, $\mathbf{T N}=$ total nitrogen, WSN = water-soluble nitrogen .

Received: June 3, 2003

Accepted: October 20, 2003.

Corresponding author: J.-C. Vuillemard; e-mail: jean-christophe. vuillemard@aln.ulaval.ca.

\section{INTRODUCTION}

Biochemical changes that occur in cheeses during ripening are of great importance to the development of desirable textural and sensorial properties of ripened cheeses. Because ripening is a slow and therefore a costly process, many researchers have attempted to develop more intense cheese flavor in a shorter period of time. Fox (1988), Law (1990), Dako et al. (1995), Klein and Lortal (1999), Madkor et al. (2000), and El Soda et al. (2000a) suggested the use of exogenous enzymes or attenuated bacteria to accelerate cheese flavor development. This method increases peptidase activity in the cheese curd and consequently proteolysis. Kheadr et al. (2000) recommended the use of encapsulated bacterial proteinase or fungal proteinase (at concentrations of $10^{-5}$ and $2 \times 10^{-6}$ Anson unit/g cheese curd, respectively) to accelerate Cheddar cheese ripening without producing flavor or texture defects. They also studied the acceleration of cheese lipolysis by using liposomeentrapped lipases (Kheadr et al., 2002) or enzyme cocktails (Kheadr et al., 2003). The use of liposomes as enzyme carriers appeared to decrease the flavor defects that usually result from the addition of free enzymes.

Other studies have shown that adjunct cultures of Lactobacillus make useful contributions to flavor development (El Soda et al., 2000b) and texture changes (Oommen et al., 2002) during maturation. Puchades et al. (1989) observed an increase in free amino acids during ripening of lactobacilli-added cheeses, whereas El Abboudi et al. (1990) reported improved flavor due to increased levels of the methyl ketone in cheese made with Lactobacillus casei ssp. casei L2A. Trépanier et al. (1991) obtained an increase in Cheddar cheese flavor intensity of about $40 \%$ by adding this strain of lactobacilli. Certain criteria must be respected when selecting adjunct cultures, the most important being autolysis and proteolysis characteristics of the added strain (Awad et al., 2000; Hannon et al., 2003). Lactobacilli are generally regarded as the most suitable (Lynch et al., 1996), although El Soda et al. (1999) demonstrated that some lactobacilli adjuncts autolyzed very slowly 
and released low levels of peptidase and esterase activities in cheese slurry.

In a recent study, we characterized the aminopeptidase, dipeptidase, and endopeptidase activities of the autolytic Lactobacillus delbrueckii ssp. bulgaricus UL12, and determined its sensitivity to nisin Z (Sallami, 2003). Our objective in the present study was to investigate the impact of autolytic Lactobacillus delbrueckii subsp. bulgaricus UL12 and nisin Z-producing Lactococcus lactis subsp. lactis biovar diacetylactis UL719 on viable cell counts and biochemical, as well as textural, attributes during Cheddar cheese ripening in comparison with the use of the proteolytic strain Lactobacillus casei subsp. casei L2A.

\section{MATERIALS AND METHODS}

\section{Cheese Starter and Adjunct Cultures}

Lactobacillus delbrueckii subsp. bulgaricus UL12, a highly autolytic strain (Kang et al., 1998) (Lb. bulgaricus UL12) and Lactococcus lactis subsp. lactis biovar diacetylactis UL719 (Lc. diacetylactis UL719), a nisin Zproducing strain (Meghrous et al., 1997), were obtained from the STELA Dairy Research Centre (Laval University, Quebec, PQ, Canada). Lactobacillus casei subsp. casei L2A (Lb. casei L2A) was obtained from the Agriculture and Agri-food Canada Food Research Institute (Ottawa, ON, Canada). Lc. lactis subsp. lactis KB (Lc. lactis $\mathrm{KB}$ ) and Lc. lactis subsp. cremoris $\mathrm{KB}$ (Lc. cremoris $\mathrm{KB}$ ) were obtained from Ezal Rhône-Poulenc Inc. (Mississauga, ON, Canada). All strains were maintained at $-80^{\circ} \mathrm{C}$ in $11 \%$ sterile reconstituted skim milk (RSM) supplemented with $20 \%$ (vol/vol) glycerol. Lactobacilli were grown in de Man, Rogosa, and Sharpe (MRS) broth (De Man et al., 1960) (Institut Rosell Inc., Montreal, PQ, Canada) under anaerobic conditions in Oxoid jars using the Oxoid anaeroGenTM (Oxoid Ltd., Basingstoke, Hampshire, England) atmosphere generation system at $37^{\circ} \mathrm{C}$ for $48 \mathrm{~h}$. Lactococci were grown in M17 broth (BDH-Merck, Darmstadt, Germany), supplemented with $0.5 \%$ (wt/vol) glucose, and incubated overnight at $30^{\circ} \mathrm{C}$ (Terzaghi and Sandine 1975). Each strain was subcultured $(1 \% \mathrm{vol} / \mathrm{vol}) 3$ times and then transferred to $11 \%$ RSM for overnight incubation to produce the cheese starter cultures.

\section{Cheese-Making Procedure}

All starters contained Lc. lactis $\mathrm{KB}$ and Lc. cremoris KB RSM cultures at a ratio of $1: 1$ ( $\mathrm{vol} / \mathrm{vol})$, which were selected for high acidifying capacity and nisin $\mathrm{Z}$ tolerance (Benech et al., 2002a). Nisin-producing Lc. diacetylactis UL719 cultures was added at one-fourth the lactococcal culture volume and $L b$. bulgaricus UL12 and $L b$. casei $\mathrm{L} 2 \mathrm{~A}$ were added to cheese milk to obtain a concentration of $10^{5}$ to $10^{6} \mathrm{cfu} / \mathrm{mL}$. The experimental cheeses and their codes are given in Table 1. Before inoculation, cheese milk was pasteurized at $72^{\circ} \mathrm{C}$ for $16 \mathrm{~s}$ and cooled to $4^{\circ} \mathrm{C}$. The destruction of indigenous lactobacilli was confirmed by plating on MRS agar. The cheese milk was warmed up to $32^{\circ} \mathrm{C}$, inoculated with $1.5 \%$ (vol/vol) starter culture, and Cheddar cheese was produced following the standard procedure (Kosikowski, 1982). Blocks were then vacuum packed in plastic film (4-mm thickness, Winpax Co., Winnipeg, MB, Canada), coded, and ripened at $7^{\circ} \mathrm{C}$ for 6 mo. Samples were analyzed at 0 (pressed curd ), 1, 3, and 6 mo.

\section{Cheese Analysis}

Moisture, total nitrogen (TN), and ash contents of cheese samples were determined in duplicate (AOAC, 1990). The fat content of cheese samples was determined by the Babcock-fat test described by Bartels et al. (1987). Cheese pH was measured using a Spear Tip combination electrode model 430 (Corning Inc., Corning, NY). Titratable acidity (TA) was determined by the method developed by Lau et al. (1991). Free fatty acids (acid values) were determined as described by Drake et al. (1998). The cheese yield was expressed as the ratio mass between the curd obtained after pressing stage and the weight of milk.

\section{Microbiological Analyses}

Cheese samples (10 g) were homogenized for $3 \mathrm{~min}$ with $90 \mathrm{~mL}$ of a sterile $2 \%$ sodium citrate solution in a Lab Blender 80 Stomacher (Seward Medical, London, UK) (Guerzoni et al., 1999) and serially diluted 10-fold using $2 \%$ sodium citrate. Appropriate dilutions were plated on KMK agar and incubated aerobically at $37^{\circ} \mathrm{C}$ for $72 \mathrm{~h}$ to enumerate lactococci (Kempler and McKay, 1980). The $L b$. bulgaricus UL12 was enumerated by plating on MRS agar containing $1 \mathrm{IU} / \mathrm{mL}$ of penicillin G (Sigma Chemical Co., St. Louis, MO), whereas $L b$. casei L2A was plated on MRS agar and acidified to $\mathrm{pH}$ 5.6. Both were incubated anaerobically at $37^{\circ} \mathrm{C}$ for $72 \mathrm{~h}$.

\section{Proteolysis}

Water-soluble nitrogen determination. Fat-free cheese homogenates were prepared according to the method developed by Kuchroo and Fox (1982) to follow the evolution of cheese proteolysis. Water-soluble nitrogen (WSN) was determined by the Kjeldahl method (International Dairy Federation, 1993).

Measurement of free amino acids. The cadmiumninhydrin method of Folkertsma and Fox (1992) was 
Table 1. Starter and adjunct bacterial mixture for each treatment. ${ }^{1}$

\begin{tabular}{llllll}
\hline \multicolumn{5}{c}{ Bacterial strain } \\
\cline { 2 - 6 } Code & Lc. cremoris & Lc. lactis & Lc. diacetylactis & Lb. bulgaricus & Lb. casei \\
\hline LL & $\mathrm{KB}$ & $\mathrm{KB}$ & $\mathrm{UL719}^{2}$ & $\mathrm{UL12}^{3}$ & L2A $^{3}$ \\
LLB & + & + & - & - & - \\
LLA & + & + & - & + & - \\
LLD & + & + & - & - & + \\
LLDB & + & + & - & + & - \\
\hline
\end{tabular}

${ }^{1}$ All cheeses were made using a 1:1 (vol/vol) mixed starter culture of Lactococcus lactis subsp. cremoris $\mathrm{KB}$ and Lactococcus lacti, subsp. lactis KB. Mixed starter was inoculated in milk to achieve final concentration of $1.5 \%(\mathrm{vol} / \mathrm{vol})$.

${ }^{2} \mathrm{Nisin}$ Z-producing strain was incorporated into cheese culture at level of $25 \%$ (vol/vol).

${ }^{3}$ Lactobacilli strains were added at the level of $10^{5}$ to $10^{6} \mathrm{cfu} / \mathrm{mL}$.

${ }^{4}+$ and - indicate presence or absence.

used to quantify free amino acids produced during Cheddar cheese ripening. Lyophilized WSN extracts were reconstituted in distilled water $(10 \%, \mathrm{wt} / \mathrm{vol})$, and a 50- $\mu \mathrm{L}$ sample was diluted to $1 \mathrm{~mL}$ with distilled water and added to $2 \mathrm{~mL}$ of Cd-ninhydrin reagent $(0.8 \mathrm{~g}$ ninhydrin [Sigma] in $80 \mathrm{~mL}$ of $95 \%$ ethanol and $10 \mathrm{~mL}$ of glacial acetic acid, to which $1 \mathrm{~g}$ of $\mathrm{CdCl}_{2}$ [Sigma] previously dissolved in $1 \mathrm{~mL}$ of distilled water is added). The mixture was heated at $84^{\circ} \mathrm{C}$ for $5 \mathrm{~min}$, cooled, and the absorbence at $507 \mathrm{~nm}$ was determined using an Agilent 8453 UV-visible spectrophotometer (Agilent Inc., Palo Alto, CA). The concentration of free amino groups in the mixture was expressed as $\mathrm{m} M$ leucine equivalent/L ( $\mathrm{m} M$ Leu. eq/L ) using a standard curve of D-L-Leucine (Sigma).

\section{Textural Measurement}

Texture profile analyses were performed on cheese samples using the double compression test (TA-XT2 Texture Analyzer, Texture Technologies, Carry, NY). Ten cylindrical portions $(1 \mathrm{~cm}$ high and $1 \mathrm{~cm}$ in diameter) of cheese were removed with a cork borer and held in sealed containers at room temperature for $1 \mathrm{~h}$ before testing. Samples were compressed to $80 \%$ of their original height at a compression speed of $2 \mathrm{~cm} \mathrm{~min}^{-1}$. The following parameters were evaluated according to the definitions given by the International Dairy Federation (1991):

Hardness: the force in Newtons $(\mathrm{N})$ required to attain a given deformation.

Fracturability: the force in Newtons (N) at which the material fractures.

Springiness or elasticity (no dimension): the extent at which a deformed material goes back to its undeformed condition after the deforming force is removed.

\section{Statistical Analysis}

Cheese-making treatments were performed in triplicate, and each analysis was done in duplicate. Statistical analyses were performed with STATGRAPHICS plus 4.1 (Manugistics, Inc., Rockville, MD). The differences between treatments were tested by analysis of variance. Treatment comparisons were performed using Fisher's least-significant differences (LSD). The level of significance was $P<0.05$.

\section{RESULTS AND DISCUSSION}

\section{Chemical Composition of Cheeses}

The gross chemical composition of experimental Cheddar cheeses is summarized in Table 2. The main compositional differences were observed between lactobacilli-containing and lactobacilli-free cheeses. Lactobacilli-containing cheeses had significantly higher moisture, and the protein content was higher in cheeses containing both $L b$. bulgaricus UL12 and Lc. diacetylactis UL719 (LLDB) strains. Cheese yields were not significantly different except for LLD cheeses (slightly lower) and LLB cheeses (slightly higher).

\section{Viable Cell Enumeration}

The evolution of the total lactococci counts during ripening in the experimental cheeses is shown in Figure 1. There was no significant difference in the number of lactococci in the freshly pressed cheese blocks. A gradual decline in viable lactococci was noted as ripening progressed, resulting in a 2-log reduction after 6 mo. This result was in agreement with those reported by Wilkinson et al. (1994), who showed a decline in lactococci viable counts in Cheddar cheese from approximately $10^{9}$ to $10^{6}$ to $10^{7} \mathrm{cfu} / \mathrm{g}$ ( 0.1 to $1 \%$ viability) after 
Table 2. Chemical composition and yield of experimental cheeses on day of manufacture. ${ }^{1}$

\begin{tabular}{llllll}
\hline & \multicolumn{4}{c}{ Mean \pm standard error } \\
\cline { 2 - 6 } Code & Fat $(\%)$ & Moisture $(\%)$ & Ash $(\%)$ & Proteins $(\%)$ & Yield (\%) \\
\hline LL & $31.83 \pm 0.76^{\mathrm{a}}$ & $40.41 \pm 0.00^{\mathrm{b}}$ & $2.79 \pm 0.03^{\mathrm{b}}$ & $23.55 \pm 0.04^{\mathrm{bc}}$ & $10.16 \pm 0.17^{\mathrm{ab}}$ \\
LLD & $31.50 \pm 0.40^{\mathrm{a}}$ & $40.54 \pm 0.27^{\mathrm{b}}$ & $3.08 \pm 0.12^{\mathrm{a}}$ & $23.56 \pm 0.02^{\mathrm{bc}}$ & $10.06 \pm 0.38^{\mathrm{b}}$ \\
LLB & $31.00 \pm 0.55^{\mathrm{a}}$ & $41.46 \pm 0.41^{\mathrm{a}}$ & $2.93 \pm 0.08^{\mathrm{ab}}$ & $23.47 \pm 0.00^{\mathrm{c}}$ & $10.54 \pm 0.07^{\mathrm{a}}$ \\
LLDB & $31.66 \pm 0.28^{\mathrm{a}}$ & $41.50 \pm 0.38^{\mathrm{a}}$ & $2.92 \pm 0.12^{\mathrm{ab}}$ & $24.41 \pm 0.01^{\mathrm{a}}$ & $10.34 \pm 0.24^{\mathrm{ab}}$ \\
LLA & $31.00 \pm 0.28^{\mathrm{a}}$ & $41.40 \pm 0.01^{\mathrm{a}}$ & $2.86 \pm 0.02^{\mathrm{b}}$ & $23.67 \pm 0.12^{\mathrm{b}}$ & $10.26 \pm 0.30^{\mathrm{ab}}$ \\
\hline
\end{tabular}

${ }^{1}$ All cheeses were made using a 1:1 (vol/vol) mixed starter culture of Lactococcus lactis subsp. cremoris $\mathrm{KB}$ and Lactococcus lacti, subsp. lactis KB. Mixed starter was inoculated in milk to achieve final concentration of $1.5 \%(\mathrm{vol} / \mathrm{vol})$.

${ }^{2}$ Means within the same columns with different subscriptions are significantly different $(P<0.05)$.

4 mos of ripening. Midje et al. (2000) also reported that starter culture cell populations reach a maximum during, or shortly after, Cheddar cheese manufacture and decrease thereafter.

The viable counts of $L b$. casei L2A increased significantly during the first month, remained stable after 3 mo, and decreased slightly after 6 mo (Figure 2). This growth profile has been previously reported for $L b$. casei L2A in Cheddar cheese by Trépanier et al. (1992) and by Benech et al. (2003). The high cell counts of $L b$. casei L2A observed at the day of manufacture may indicate its growth during cheese pressing.

In the case of $L b$. bulgaricus UL12, the initial viable number determined in milk following the inoculation process was $10^{7} \mathrm{cfu} / \mathrm{mL}$ (data not shown). Whereas its number in freshly pressed cheese blocks was much

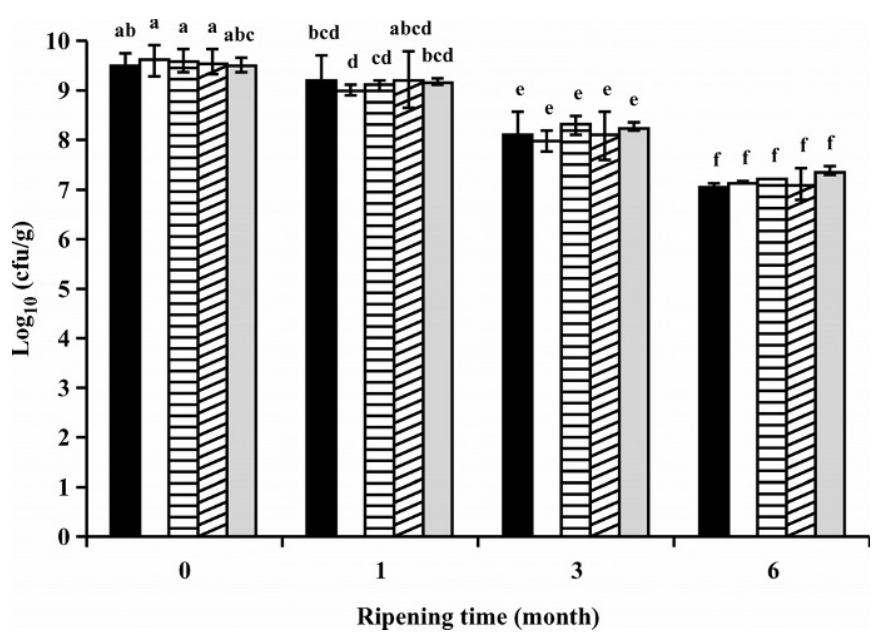

Figure 1. Changes in lactococcal viable counts in Cheddar cheeses. Lactococcus cremoris $\mathrm{KB}+$ Lactococcus lactis KB (LL) (black bar); Lc. cremoris $\mathrm{KB}+$ Lc. lactis $\mathrm{KB}+$ Lactobacillus bulgaricus $\mathrm{UL} 12$ (LLB) (white bar); Lc. cremoris $\mathrm{KB}+$ Lc. lactis $\mathrm{KB}+$ Lactobacillus casei L2A (LLA) (horizontal striped bar); Lc. cremoris $\mathrm{KB}+$ Lc. Lactis $\mathrm{KB}+$ Lactococcus diacetylactis UL719 (LLD) (diagonal striped bar) and Lc. cremoris $\mathrm{KB}+$ Lc. lactis $\mathrm{KB}+$ Lc. diacetylactis $\mathrm{UL719}+L b$. bulgaricus UL12 (LLDB) (gray bar). Means without common letters are significantly different $(P<0.05)$. lower at approximately $10^{3}$ and $10^{2} \mathrm{cfu} / \mathrm{g}$ in LLB and LLDB cheeses, respectively. In a previous study on Swiss type cheese, it was demonstrated that autolysis occurred early and coincided with a drastic reduction in lactobacilli counts (Valence et al., 1998). The autolysis of $L b$. helveticus was later found to decrease cell counts from $10^{8}$ to $10^{3} \mathrm{cfu} / \mathrm{g}$ after $40 \mathrm{~d}$ and to reach $10^{2}$ $\mathrm{cfu} / \mathrm{g}$ after $100 \mathrm{~d}$ of aging (Valence et al., 2000). In the present study, low viable counts of $L b$. bulgaricus UL12, determined in both LLB and LLDB cheeses, may indicate high autolytic activity of $L b$. bulgaricus UL12 and/ or attributed to the cheese-making process and incorporating Lc. diacetylactis UL719, which reduced the viability of $L b$. bulgaricus UL12 and/or induced its autolytic activity. Higher autolytic activity of $L b$. bulgaricus $\mathrm{UL} 12$ has been reported at $40^{\circ} \mathrm{C}$ in the presence of 0.2 $M \mathrm{NaCl}$ (Kang et al., 1998) and conditions close to these are encountered during cheese scalding, cheddaring, and salting procedures. Concerning nisin Z sensitivity

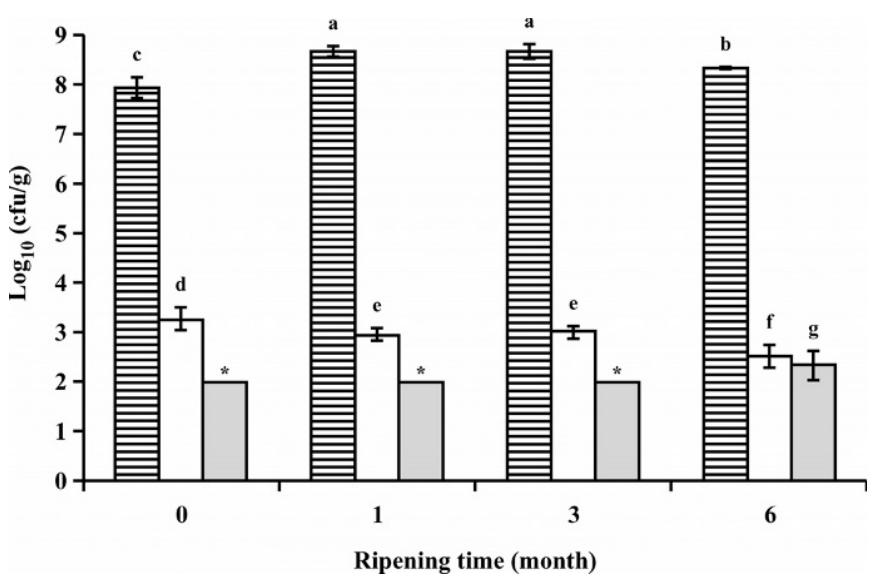

Figure 2. Changes in lactobacilli viable counts in Cheddar cheeses. Lactococcus cremoris $\mathrm{KB}+$ Lactococcus lactis $\mathrm{KB}+$ Lb. casei $\mathrm{L} 2 \mathrm{~A}$ (LLA) (horizontal striped bar); Lc. cremoris $\mathrm{KB}+$ Lc. lactis $\mathrm{KB}+$ Lactobacillus bulgaricus UL12 (LLB) (white bar) and Lc. cremoris $\mathrm{KB}+$ Lc. lactis $\mathrm{KB}+$ Lactococcus diacetylactis $\mathrm{UL} 719+$ Lb. bulgaricus UL12 (LLDB) (gray bar). *Viable cells were $<10^{2} \mathrm{cfu} / \mathrm{g}$. Means without common letters are significantly different $(P<0.05)$. 


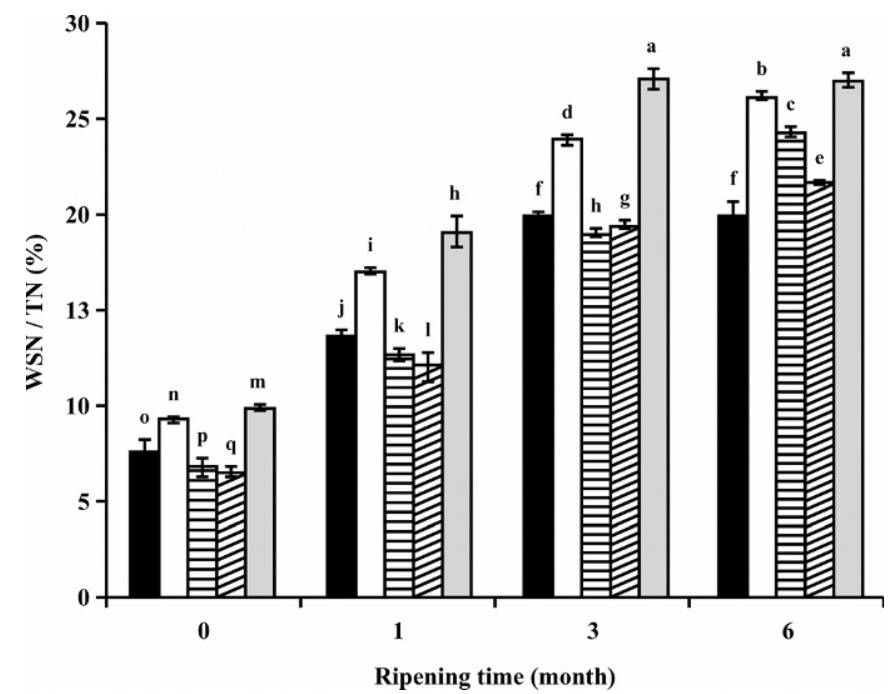

Figure 3. Evolution of water-soluble nitrogen (WSN), in relation to total nitrogen (TN), in Cheddar cheeses. Lactococcus cremoris $\mathrm{KB}$ + Lactococcus lactis $\mathrm{KB}$ (LL) (black bar); Lc. cremoris $\mathrm{KB}+$ Lc. lactis $\mathrm{KB}+$ Lactobacillus bulgaricus UL12 (LLB) (white bar); Lc. Cremoris $\mathrm{KB}+$ Lc. Lactis $\mathrm{KB}+$ Lb. casei L2A (LLA) (horizontal striped bar); Lc. cremoris $\mathrm{KB}+$ Lc. lactis $\mathrm{KB}+$ Lactococcus diacetylactis $\mathrm{UL} 719$ (LLD) (diagonal striped bar); and Lc. cremoris $\mathrm{KB}+$ Lc. lactis $\mathrm{KB}+$ Lc. diacetylactis UL719 + Lb. bulgaricus UL12 (LLDB) (gray bar). Means without common letters are significantly different $(P<0.05)$.

of this strain, we reported in a recent study (Sallami et al., submitted) that a nisin $\mathrm{Z}$ concentration of 3.75 $\mu \mathrm{g} / \mathrm{mL}$ was found to inhibit completely $L b$. bulgaricus UL12 in broth suspension. The production of nisin Z by Lc. diacetylactis UL719 in Cheddar cheese at the day of manufacture was previously determined by Benech et al. (2002a) to be $7.5 \mu \mathrm{g} / \mathrm{mL}$ (300 IU/g). Nisininduced lysis of starter adjuncts with high peptidase activity (Lb. Casei, subsp. casei IFPL731) in cheese containing a nisinogenic strain was found to accelerate Cheddar cheese ripening (Martínez-Cuesta et al., 1997, 1998).

It should be noted that decreases in lactobacilli counts cannot generally be regarded as a reliable indicator of lysis. Part of the initial population may simply fail to grow in the complex matrix of cheese and die (Wilkinson et al., 1995). In the present study, however, the high level of WSN observed in cheeses with $L b$. bulgaricus UL12 (Figure 3) suggests that the decrease in viable lactobacilli was probably followed by cell autolysis.

\section{pH and Titratable Acidity}

The $\mathrm{pH}$ values of experimental cheeses determined during ripening are given in Table 3 . The incorporation of such lactobacilli (LLB and LLA cheeses) did not appear to have significant effect on cheese $\mathrm{pH}$ values on the day of manufacture. However, cheeses with added Lc. diacetylactis UL719 (LLD and LLDB cheeses) showed significantly $(P<0.05)$ higher $\mathrm{pH}$ values compared with the control cheese (LL cheeses). On aging, there was a continued drop in $\mathrm{pH}$ values of all cheeses, and the major $\mathrm{pH}$ reduction was observed during the first month of ripening; thereafter, the process slowed down. From the first month, lactobacilli-containing cheeses exhibited significantly lower $\mathrm{pH}$ values compared with control cheese and Lc. diacetylactis UL719containing cheeses. Lower $\mathrm{pH}$ values for lactobacillicontaining Cheddar cheeses were previously reported by Trépanier et al. (1991, 1992). The authors attributed this finding to the continued production of lactic acid by live cells of lactobacilli that could survive much longer in cheese than lactococci, and/or the liberation of certain amino acids, such as aspartic and glutamic acids, that could influence cheese $\mathrm{pH}$. Meanwhile, $L b$. bulgaricus UL12 used in this study is a lactose-negative strain (Sallami, 2003), and it could be concluded that the lower $\mathrm{pH}$ values reported herein for Lb. bulgaricuscontaining cheeses are probably due to its ability to release acidic amino acids rather than fermenting residual lactose in the cheese matrix. This was further confirmed by higher titratable acidity.

At the day of manufacture, LLB-cheeses had significantly higher TA value as compared to the other cheeses, whereas LLD cheeses exhibited the lowest TA value. The autolytic activity of $L b$. bulgaricus UL12 might be responsible for the higher TA values at that stage by releasing intracellular enzymes leading to hydrolysis of casein and large peptides to smaller peptides and amino acids that could interfere with the titration process. On the other hand, the lower TA values reported herein for LLD cheeses compared to the control cheese (LL cheeses) might be due to the inhibitory effect of nisin Z produced by Lc. diacetylactis UL719 against nisin Z-sensitive subpopulation lactococci. Although the cheese mixed culture used in this study was selected for its nisin tolerance characteristics, the presence of a nisin-sensitive subpopulation of lactococci was evident, as reported by Benech et al. (2002b). The authors have confirmed the presence of this subpopulation in Cheddar cheese using immuno electron microscopy. On aging, there was a continued increase in TA values for all cheeses, and also LLB cheeses had the highest values among cheeses. The increased TA values during cheese ripening may be correlated with increased cheese proteolysis. As casein and large peptides are hydrolyzed into low molecular weight peptides and amino acids that could be soluble in cheese water extract, their carboxyl groups could be interfered during titration by the alkaline (Lau et al., 1991). 
Table 3. $\mathrm{pH}$, titratable acidity, and acid value of Cheddar cheeses during aging.

\begin{tabular}{|c|c|c|c|c|}
\hline \multirow[b]{2}{*}{ Code $^{2}$} & \multirow[b]{2}{*}{$\begin{array}{l}\text { Cheese age } \\
\text { (month) }\end{array}$} & \multicolumn{3}{|c|}{ Mean \pm standard error ${ }^{1}$} \\
\hline & & $\mathrm{pH}$ & $\begin{array}{l}\text { Titratable acidity } \\
(\%)\end{array}$ & $\begin{array}{c}\text { Acid value } \\
\text { (mg KOH/g lyophilisate) }\end{array}$ \\
\hline $\mathrm{LL}$ & 0 & $5.025 \pm 0.021^{b c}$ & $0.90 \pm 0.029^{\mathrm{k}}$ & $7.293 \pm 0.526^{\mathrm{jk}}$ \\
\hline $\mathrm{LL}$ & 1 & $4.955 \pm 0.007^{\mathrm{de}}$ & $1.251 \pm 0.018^{\mathrm{h}}$ & $8.415 \pm 0.417^{\mathrm{hi}}$ \\
\hline LL & 3 & $4.980 \pm 0.007^{\mathrm{cd}}$ & $1.467 \pm 0.018^{\mathrm{fg}}$ & $9.537 \pm 0.390^{\mathrm{fg}}$ \\
\hline LL & 6 & $4.975 \pm 0.049^{b c}$ & $1.638 \pm 0.020^{\mathrm{d}}$ & $10.659 \pm 0.60^{\mathrm{de}}$ \\
\hline LLD & 0 & $5.175 \pm 0.035^{\mathrm{a}}$ & $0.729 \pm 0.018^{1}$ & $5.890 \pm 0.246^{\mathrm{l}}$ \\
\hline LLD & 1 & $5.040 \pm 0.042^{\mathrm{b}}$ & $1.161 \pm 0.018^{\mathrm{jk}}$ & $9.256 \pm 0.396^{\mathrm{gh}}$ \\
\hline LLD & 3 & $5.055 \pm 0.007^{\mathrm{b}}$ & $1.260 \pm 0.029^{\mathrm{h}}$ & $10.378 \pm 0.30^{\mathrm{ef}}$ \\
\hline LLD & 6 & $5.040 \pm 0.042^{\mathrm{b}}$ & $1.485 \pm 0.054^{\mathrm{f}}$ & $10.939 \pm 0.49^{\mathrm{de}}$ \\
\hline LLB & 0 & $5.030 \pm 0.014^{\mathrm{bc}}$ & $1.089 \pm 0.034^{\mathrm{j}}$ & $7.573 \pm 0.213^{\mathrm{ij}}$ \\
\hline LLB & 1 & $4.910 \pm 0.007^{\mathrm{efg}}$ & $1.476 \pm 0.041^{\mathrm{fg}}$ & $9.256 \pm 0.36^{\mathrm{gh}}$ \\
\hline LLB & 3 & $4.880 \pm 0.028^{\mathrm{g}}$ & $1.629 \pm 0.034^{\mathrm{d}}$ & $10.939 \pm 0.496^{\mathrm{de}}$ \\
\hline LLB & 6 & $4.815 \pm 0.007^{\mathrm{h}}$ & $1.935 \pm 0.018^{\mathrm{a}}$ & $12.622 \pm 0.295^{\mathrm{b}}$ \\
\hline LLDB & 0 & $5.215 \pm 0.035^{\mathrm{a}}$ & $0.873 \pm 0.018^{\mathrm{k}}$ & $6.451 \pm 0.33^{\mathrm{kl}}$ \\
\hline LLDB & 1 & $5.030 \pm 0.056^{\mathrm{bc}}$ & $1.440 \pm 0.029^{\mathrm{g}}$ & $12.061 \pm 0.276^{\mathrm{bc}}$ \\
\hline LLDB & 3 & $4.965 \pm 0.007^{\mathrm{de}}$ & $1.854 \pm 0.020^{\mathrm{bc}}$ & ND \\
\hline LLDB & 6 & $4.940 \pm 0.014^{\mathrm{def}}$ & $1.881 \pm 0.054^{\mathrm{b}}$ & $15.427 \pm 0.396^{\mathrm{a}}$ \\
\hline LLA & 0 & $5.030 \pm 0.014^{\mathrm{bc}}$ & $0.873 \pm 0.018^{\mathrm{k}}$ & $7.573 \pm 0.306^{\mathrm{ij}}$ \\
\hline LLA & 1 & $4.980 \pm 0.007^{\mathrm{cd}}$ & $1.224 \pm 0.029^{\mathrm{jk}}$ & $8.274 \pm 0.198^{\text {hij }}$ \\
\hline LLA & 3 & $4.880 \pm 0.014^{\mathrm{g}}$ & $1.575 \pm 0.034^{\mathrm{e}}$ & $10.378 \pm 0.168^{\mathrm{ef}}$ \\
\hline LLA & 6 & $4.885 \pm 0.007^{\mathrm{fg}}$ & $1.818 \pm 0.020^{\mathrm{c}}$ & $11.50 \pm 0.396^{\mathrm{cd}}$ \\
\hline
\end{tabular}

${ }^{1}$ Means within the same columns without common superscripts are significantly different $(P<0.05)$.

${ }^{2}$ See Table 1.

ND: Not determined.

\section{Lipolysis}

Lipolysis was determined as a term of acid value (expressed as $\mathrm{mg}$ of $\mathrm{KOH} / \mathrm{g}$ of freeze-dried cheese) and increased gradually with increasing ripening time (Table 3). Cheeses with added lactobacilli showed higher acid values from the day of manufacture. Moreover, cheeses containing $L b$. bulgaricus UL12 exhibited a higher acid value than did those with $L b$. casei L2A, and $L b$. bulgaricus UL12, together with the nisin Zproducing strain, produced even higher values. High acid values in cheeses containing a nisin-producing strain has been previously reported by Benech et al. (2003) and attributed to the autolysis of nisin-sensitive subpopulations of cheese starter cultures. Increased lipolysis in lactobacilli-containing cheeses may thus be attributed to the release of intracellular esterases and lipases. The difference between lipolysis in LLB and LLA cheeses may be due to potential esterase activities for the liberation of $\mathrm{C}_{8: 0}$ and $\mathrm{C}_{14: 0}$ by $L b$. bulgaricus UL12, which were absent in Lb. casei L2A (Sallami et al., 2003). In Cheddar cheese made with an autolytic strain of Lc. lactis subsp. cremoris AM2, Collins et al. (2003) observed higher levels of caprylic, myristic, palmitic, and stearic during ripening, compared with cheese made with a nonautolytic strain of Lc. lactis subsp. cremoris HP. Authors correlated increased cell autolysis with an increased level of lipolysis during Cheddar cheese ripening. For lactobacilli, Kanawija et al. (1993) reported that lysis liberates intracellular lipase and may account for much of the lipolytic activity in cheese. Commonly, acid values follow the same trend as soluble nitrogen, suggesting that factors affecting the proteolysis have the same effect on lipolysis activity (Kebary et al., 1996).

\section{Proteolysis}

Water-soluble nitrogen. The WSN content of all experimental cheeses increased over the ripening period (Figure 3). Water-soluble nitrogen production in LL and LLD cheeses differed only slightly, which is in agreement with the study of Morgan et al. (1997), who reported no obvious differences in WSN for Cheddar cheeses manufactured with or without bacteriocin-producing adjunct cultures. In contrast, lactobacilli-containing cheeses had significantly higher WSN levels than lactobacilli-free cheeses. A similar observation was reported by Ommen et al. (2002) who studied the effects of the proteolytic specificities toward $\alpha_{\mathrm{s} 1}$ casein of 3 different Lc. delbrueckii subsp. bulgaricus, on the functional properties of Mozzarella cheese, in which lactobacilli produced 2.2-, 2.4-, and 2.7-fold more watersoluble nitrogen compared to controls made using Streptococcus thermophilus alone.

Compared with LL cheeses Lactobacillus bulgaricus UL12 produced significantly more WSN (3.87, 10.0, 14.7, and $18.42 \%)$ than $L b$. casei L2A $(3.84,1.66,8.82$, 


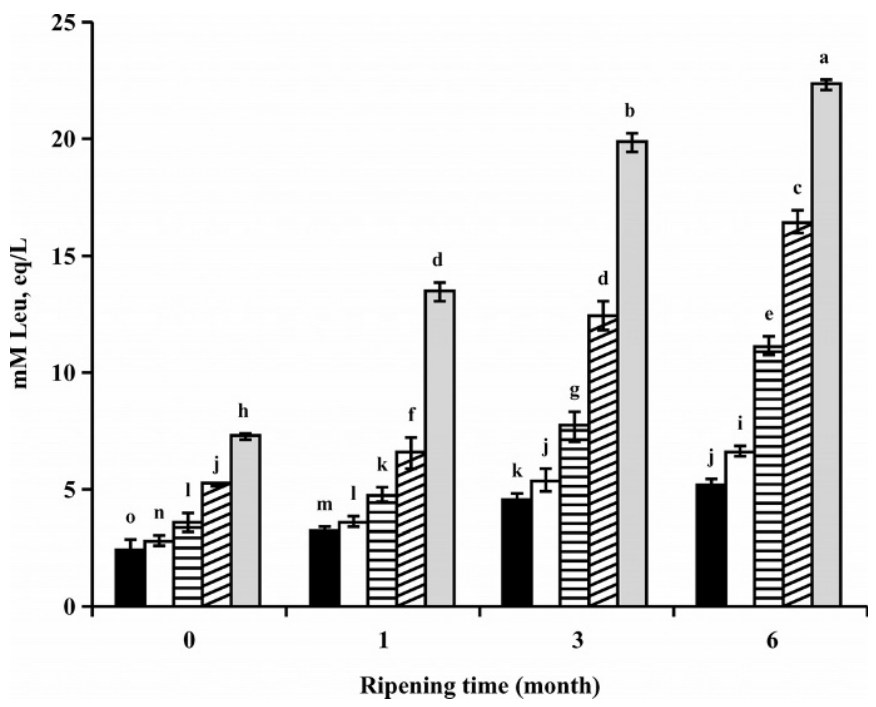

Figure 4. Concentration of free amino acids in water-soluble extract determined as $\mathrm{m} M$ equivalent leucine/L of Cheddar cheeses. Lactococcus cremoris $\mathrm{KB}+$ Lactococcus lactis KB (LL) (black bar); Lc. cremoris $\mathrm{KB}+$ Lc. lactis $\mathrm{KB}+$ Lactobacillus bulgaricus $\mathrm{UL} 12$ (LLB) (white bar); Lc. cremoris $\mathrm{KB}+$ Lc. lactis $\mathrm{KB}+$ Lb. casei $\mathrm{L} 2 \mathrm{~A}$ (LLA) (horizontal striped bar); Lc. cremoris $\mathrm{KB}+$ Lc. lactis $\mathrm{KB}+$ Lactococcus diacetylactis UL719 (LLD) (diagonal striped bar) and $L c$. cremoris $\mathrm{KB}+$ Lc. lactis $\mathrm{KB}+$ Lc. diacetylactis $\mathrm{UL} 719+L b$. bulgaricus UL12 (LLDB) (gray bar). Means without common letters are significantly different $(P<0.05)$.

and $7.89 \%$ ) at $0,1,3$, and 6 mo of ripening, respectively, compared with LL cheeses. This is consistent with our previous study on the proteolytic activity of these 2 strains in RSM (Sallami et al., submitted). Lb. bulgaricus UL12 appears to be more proteolytic than $L b$. casei L2A and may be potentially useful for accelerating cheese proteolysis and enhancing flavor.

The combination of Lb. bulgaricus UL12 and Lc. diacetylactis UL719 was the most effective at increasing the WSN content. As shown by the viable cell counts (Figure 2), the presence of $L c$. diacetylactis UL719 likely accelerated the autolysis of $L b$. bulgaricus UL12 and consequently the release of intracellular enzymes and proteolysis. Martínez-Cuesta et al. (2000) reported a high release of peptidase activity following the autolysis of Lc. lactis MG 1363 during incubation with 300 arbitrary units (AU) of nisin produced by Lc. lactis IFPL105. Awad et al. (2001) demonstrated that lactobacilli cell lysis released intracellular proteolytic enzymes in cheese slurry, decreasing the residual percentage of $\alpha_{\mathrm{s} 1^{-}}$and $\beta$-CN fractions within $30 \mathrm{~d}$ of incubation.

Free amino acids. Amino acid release, expressed as $\mathrm{m} M$ leucine equivalent in water-soluble extracts of experimental cheeses at different ripening stages, is presented in Figure 4. Free amino acid concentration increased significantly as ripening progressed. The nisin-producing strain increased free amino acid levels faster than either Lactobacillus strain from the day of manufacture, which may be attributable to the autolysis of a nisin-sensitive subpopulation of the cheese starter. Wouters et al. (2002) emphasized the importance of bacteriocin-producing strains not only for antimicrobial activity but also for their potential to develop flavor compounds during cheese ripening. Increased proteolysis in Cheddar cheese by nisin-producing $L c$. diacetylactis UL719 has been demonstrated recently by Benech et al. (2003) and attributed to a major increase in free amino acids and small peptides released from nisin-sensitive Lc. lactococci.

Lactobacillus casei L2A was more effective than $L b$. bulgaricus UL12 at releasing amino acids, which may be due to greater aminopeptidase activity (Sallami et al., submitted). Lb. casei is known to be a highly proteolytic lactobacilli and possesses several aminopeptidases with caseinolytic activity, resulting in the acceleration of Cheddar cheese proteolysis (El Abboudi et al., 1991).

In comparison, the incorporation of Lc. diacetylactis UL719, together with $L b$. bulgaricus UL12, induced the highest amino acid production, probably due to the lytic synergy between $L b$. bulgaricus UL12 and Lc. diacetylactis UL719 and its impact on starter lactococci. It has been shown that $L b$. bulgaricus UL12 exhibited relatively low aminopeptidase activity but high dipeptidase and endopeptidase activities (Sallami et al., submitted). It should thus generate medium and small peptides from casein, which may subsequently be hydrolyzed by aminopeptidases and other peptidases, released from a nisin-sensitive subpopulation to free amino acids.

Farkye et al. (1995) observed that the free amino acids concentration in WSN from cheese slurries containing $L b$. delbrueckii ssp. bulgaricus $10 \mathrm{R}$, was significantly higher than those from slurries containing other nonstarter lactic acid bacteria (NSLAB) ( $L$ b. casei MIL2B), rennet, or Lc. lactis $650 \mathrm{M}$ or Lc. lactis subsp. cremoris $(62 \mathrm{M}, 70 \mathrm{M})$. Adding highly autolytic lactobacilli or those with high enzyme activity generally leads to higher concentrations of free amino acids (Madkor et al., 1999), whereas nisin enhances the cheese proteolysis by inducing additional leakage of intracellular enzymes (Martínez-Cuesta et al., 1998).

\section{Textural Parameters}

The changes in rheological parameters (hardness, fracturability, and springiness) during ripening of experimental cheeses are shown in Figures 5, 6, and 7, respectively. Generally, values for these parameters tended to decrease gradually during cheese ripening at rates that depended on the composition of the mixed starters used. On the day of manufacture, LL cheeses 


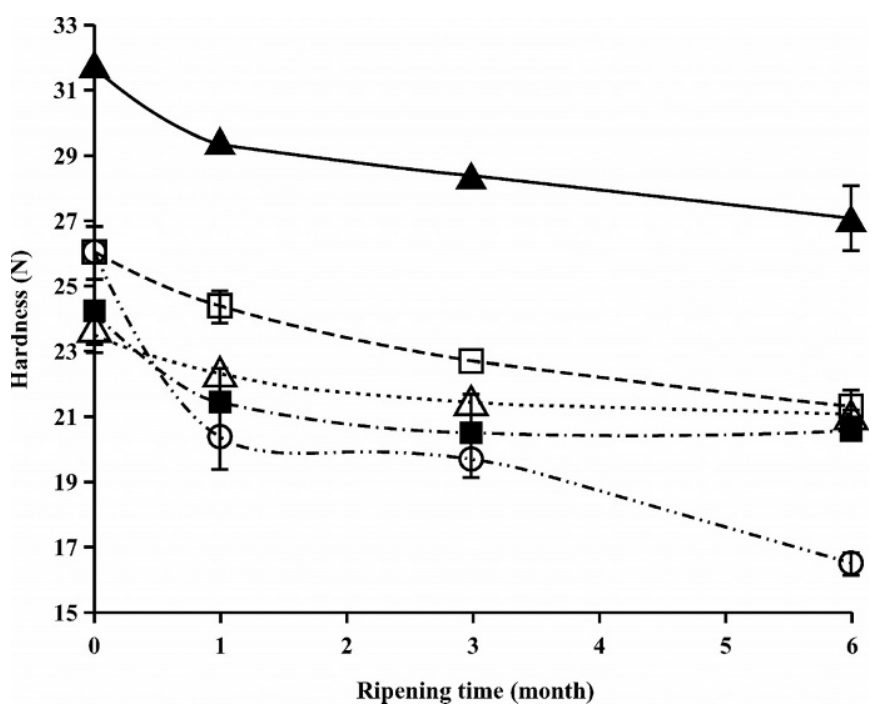

Figure 5. Evolution of hardness during ripening of Cheddar cheeses. Lactococcus cremoris $\mathrm{KB}+$ Lc. lactis $\mathrm{KB}(\mathrm{LL})(\mathbf{\Delta}) ;$ Lc. cremoris $\mathrm{KB}+$ Lc. lactis $\mathrm{KB}+$ Lactobacillus bulgaricus $\mathrm{UL12}(\mathrm{LLB})(\triangle)$; Lc. cremoris $\mathrm{KB}+$ Lc. lactis $\mathrm{KB}+$ Lactococcus diacetylactis $\mathrm{UL719}$ (LLD) (ロ); Lc. cremoris $\mathrm{KB}+$ Lc. lactis $\mathrm{KB}+$ Lc. diacetylactis $\mathrm{UL} 719$ + Lb. bulgaricus $\mathrm{UL} 12(\mathrm{LLDB})(\bigcirc)$, and Lc. cremoris $\mathrm{KB}+$ Lc. lactis $\mathrm{KB}+$ Lb. casei L2A (LLA) ( $\square)$.

were significantly harder, less brittle, and more elastic than the other cheeses. However, after 6 mo of ripening, LL cheeses had springiness values similar to those for LLA and LLB cheeses. Amantea et al. (1986) reported that during ripening, force compression of Cheddar cheese was affected by age and type of starter culture. It should be mentioned that in the case of LL and LLD cheeses, the moisture content was significantly lower than in other cheeses (Table 2) and, according to De Jong (1978), slight differences in moisture in Cheddar cheese may cause major differences in rheological parameters. Kheadr et al. (2002) correlated the decrease in values for firmness, cohesiveness, and fracturability with the increase in moisture in experimental Cheddar cheeses.

Generally, the addition of lactobacilli resulted in softer and more fracture in cheeses compared with lactobacilli-free cheeses. This effect was more pronounced for $L b$. bulgaricus-containing cheeses than for $L b$. caseicontaining cheeses. Many studies have shown a relationship between proteolysis and changes in body and texture of cheeses (Benech et al., 2003). Authors explained the increased cohesiveness and fracturability values in nisinogenic cheese containing lactobacilli strain by the increase of small peptides and free amino acids that have the ability to bind free water molecules and consequently increase the strength of the casein matrix. Fedrick and Dulley (1984) reported that fracturability, hardness, and springiness decreased with in-

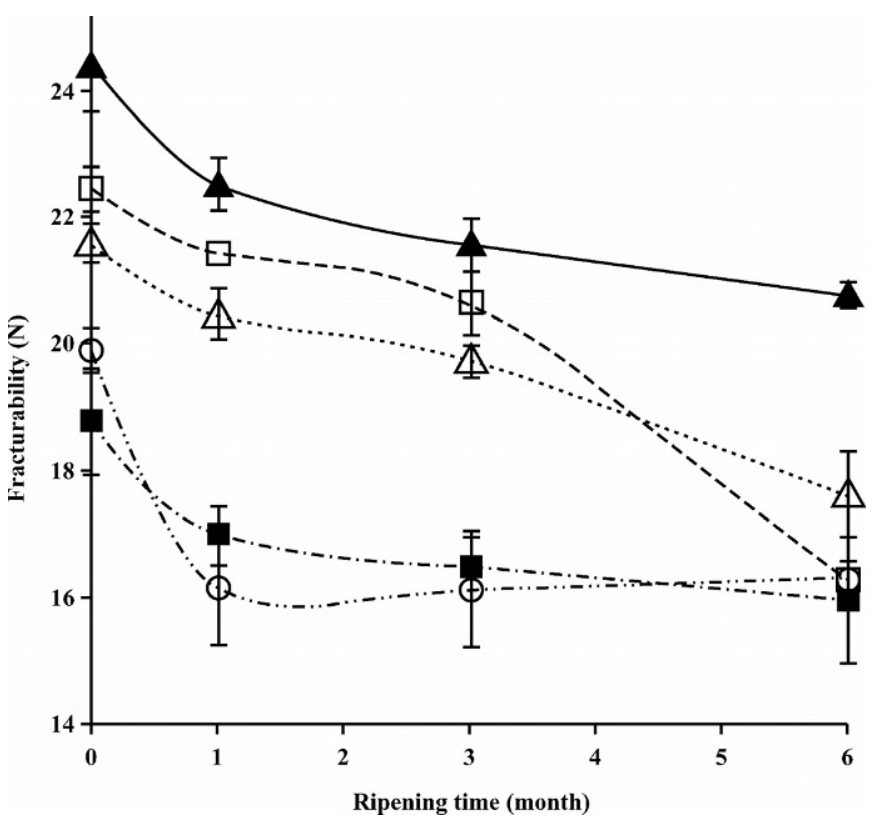

Figure 6. Evolution of fracturability during ripening of Cheddar cheeses. Lactococcus cremoris $\mathrm{KB}+$ Lactococcus lactis $\mathrm{KB}(\mathrm{LL})(\mathbf{\Delta})$; Lc. cremoris $\mathrm{KB}+$ Lc. lactis $\mathrm{KB}+$ Lactobacillus bulgaricus $\mathrm{UL} 12$ $(\mathrm{LLB})(\triangle)$; Lc. cremoris $\mathrm{KB}+$ Lc. lactis $\mathrm{KB}+$ Lactococcus diacetylactis $\mathrm{UL719}$ (LLD) (অ); Lc. cremoris $\mathrm{KB}+$ Lc. lactis $\mathrm{KB}+$ Lc. diacetylactis $\mathrm{UL} 719+L b$. bulgaricus $\mathrm{UL} 12(\mathrm{LLDB})(\bigcirc)$ and $L c$. cremoris $\mathrm{KB}+L c$. lactis $\mathrm{KB}+$ Lb. casei L2A (LLA) $(\square)$.

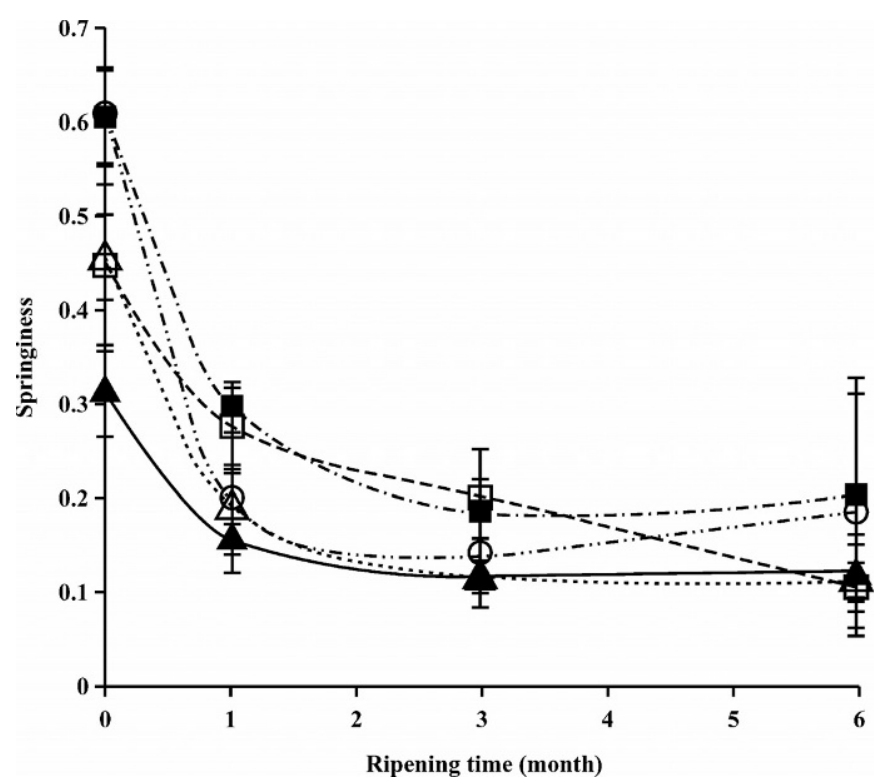

Figure 7. Evolution of springiness during ripening of Cheddar cheeses. Lactococcus cremoris $\mathrm{KB}+$ Lactococcus lactis $\mathrm{KB}(\mathrm{LL})(\mathbf{\Delta})$; Lc. cremoris $\mathrm{KB}+$ Lc. lactis $\mathrm{KB}+$ Lactobacillus bulgaricus $\mathrm{UL} 12$ $(\mathrm{LLB})(\triangle) ;$ Lc. cremoris $\mathrm{KB}+$ Lc. lactis $\mathrm{KB}+$ Lactococcus diacetylactis $\mathrm{UL719}$ (LLD) (匹); Lc. cremoris $\mathrm{KB}+$ Lc. lactis $\mathrm{KB}+$ Lc. diacetylactis $\mathrm{UL719}+$ Lb. bulgaricus UL12 (LLDB) $(\bigcirc)$ and Lc. cremoris. 
creasing cheese proteolysis. Peptidolysis is usually associated with the formation of free amino acids that may decrease fracturability, as observed for 6-mo-old LLA cheeses. Fracturability and springiness of cheeses made with the nisinogenic strain (LLD and LLDB) decreased in a very similar manner, although there were significantly different values, whereas hardness decreased more rapidly in LLDB cheeses, reflecting high levels of WSN and free amino acids (Figures 3 and 4). Casein proteolysis generally decreases values for hardness, fracturability, and springiness (Kheadr et al., 2000). Low $\mathrm{pH}$ values reported in lactobacilli-containing cheeses may be responsible for decreases in fracturing force (Creamer et al., 1988).

\section{CONCLUSION}

This study has shown the effect of incorporating a highly autolytic lactobacilli ( $L b$. bulgaricus UL12), a highly proteolytic lactobacilli ( $L b$. casei L2A), and nisinproducing strain (Lc. diacetylactis UL719) into Cheddar cheese starter cultures on the properties of resultant cheeses. Proteolysis was accelerated by using autolytic lactobacilli, whereas free amino-acid production increased by the synergetic action of the nisinogenic and proteolytic strain. The incorporation of $L b$. bulgaricus UL12 into Cheddar cheese milk resulted in significant biochemical and rheological changes in the resulting cheeses (lower $\mathrm{pH}$, high lipolytic and proteolytic activities, decreased hardness, and increased fracturability). In spite of the high autolytic character of $L b$. bulgaricus UL12, levels of free amino acids in Lb. bulgaricus-containing cheeses remained lower compared with $L b$. casei-containing cheeses. This was overcome by the addition of Lc. diacetylactis UL719, which seemed to induce proteolysis and increased the amount of free amino acids produced in Cheddar cheese.

\section{ACKNOWLEDGMENTS}

This study was made possible with the financial assistance of the Canadian Research Network on Lactic Acid Bacteria, supported by the National Sciences and Engineering Research Council of Canada, Agriculture and Agri-Food Canada, Novalait Inc., the Dairy Farmers of Canada, and Rosell-Lallemand Inc.

\section{REFERENCES}

Amantea, G. F., B. J. Skura, and S. Nakai. 1986. Culture effects on ripening characteristics and rheological behavior of Cheddar cheese. J. Food Sci. 51:912-918.

Association of Official Analytical Chemists. 1990. Paes 840-850 in Official Methods of Analysis. 15th ed. AOAC, Arlington, VA.

Awad, S., B. Bahay El Din, and M. El Soda. 2001. Proteolytic activity of Lactobacillus, Lactococcus and Enterococcus strains in pseudo- curd, casein hydrolysate and cheese slurry. Egypt. J. Dairy Sci. 29:87-97.

Awad, S., B. Bahay El Din, and M. El Soda. 2000. Autolysis and proteolysis of Lactobacillus strains in pseudo-curd and casein hydrolysate. Egypt. J. Dairy Sci. 28:139-150.

Bartels, H. J., M. E. Johnson, and N. F. Olson. 1987. Accelerated ripening of Gouda cheese. 2. Effect of freeze-shocked Lactobacillus helveticus on proteolysis and flavor development. Milchwissenschaft 42:139-144.

Benech, R. O., E. E. Kheadr, C. Lacroix, and I. Fliss. 2002a. Inhibition of Listeria innocua in Cheddar cheese by addition of nisin $\mathrm{Z}$ in liposomes or by in situ production in mixed culture. Appl. Environ. Microbiol. 68:3683-3690.

Benech, R. O., E. E. Kheadr, C. Lacroix, and I. Fliss. 2002b. Antibacterial activities of nisin $\mathrm{Z}$ encapsulated in liposomes or produced in situ by mixed culture during Cheddar cheese ripening. Appl. Environ. Microbiol. 68:5607-5619.

Benech, R. O., E. E. Kheadr, C. Lacroix, and I. Fliss. 2003. Impact of nisin producing culture and liposome-encapsulating nisin on ripening of Lactobacillus casei added-Cheddar cheese. J. Dairy Sci. 86:1895-1909.

Creamer, L. K., J. Gilles, and R. C. Lawrence. 1988. Effect of pH on the texture of Cheddar and Colby cheese. N.Z. J. Dairy Sci. Technol. 23:23-36.

Collins, Y. F., P. L. H. McSweeney, and M. G. Wilkinson. 2003. Evidence of relationship between autolysis of starter bacteria and lipolysis in Cheddar cheese during ripening. J. Dairy Res. 70:105-113.

Dako, E., M. El Soda, J. C. Vuillemard, and R. E. Simard. 1995. Autolytic properties and aminopeptidase activities of lactic acid bacteria. Food. Res. Int. 28:503-509.

De Jong, L. 1978. The influence of the moisture content on the consistency and protein breakdown of cheese. Neth. Milk Dairy J. 32:1-14.

De Man, J. C., M. Rogosa, and M. E. Sharpe. 1960. A medium for cultivation of lactobacilli. J. Appl. Bacteriol. 23:130-135.

Drake, M. A., X. Q. Chen, P. D. Gerard, and S. U. Gurkin. 1998. Composition and quality attributes of reduced-fat cheese as affected by lecithin type. J. Food Sci. 63:1018-1023.

El Abboudi, M. 1990. The production of neutral volatile compound in Cheddar cheeses during accelerated ripening. Pages 35-60 in M.Sc. Thesis. Mise au point d'un procédé de maturation accélérée du fromage Cheddar Université Laval, Québec, $\mathrm{PQ}$, Canada.

El Abboudi, M., M. El Soda, S. Pendian, M. Barreau, G. Trépanier, and R. E. Simard. 1991. Peptidase activities in debittering and nondebittering strains of lactobacilli. Int. Dairy J. 1:55-64.

El Soda, M., S. A. Madkor, and P. S. Tong. 1999. Evaluation of commercial adjuncts for use in cheese ripening: 1. Enzymatic activities and autolytic properties of freeze-shocked adjuncts in buffer system. Milchwissenschaft 54:85-89.

El Soda, M., S. A. Madkor, and P. S. Tong. 2000a. Adjuncts cultures: Recent developments and potential significance to cheese industry. A review. J. Dairy Sci. 83:609-619.

El Soda, M., S. A. Madkor, and P. S. Tong. 2000b. Evaluation of commercial adjuncts for use in cheese ripening: 4. Comparison between attenuated and not attenuated lactobacilli. Milchwissenschaft 55:260-263.

Farkye, N. Y., S. A. Madkor, and H. G. Atkins. 1995. Proteolytic abilities of some lactic acid bacteria in a model cheese system. Int. Dairy J. 5:715-725.

Fedrick, I. A., and J. R. Dulley. 1984. Effect of elevated storage temperatures on the rheology of Cheddar cheese. N.Z. J. Dairy Sci. Technol. 19:141-150.

Folkertsma, B., and P. F. Fox. 1992. Use of Cd-ninhydrin reagent to assess proteolysis in cheese during ripening. J. Dairy Res. 59:217-224.

Fox, P. F. 1988. Rennets and their action in cheese manufacture and ripening. Biotechnol. Appl. Biochem. 10:522-535.

Guerzoni, M. E., L. Vannini, C. Chaves Lopez, R. Lanciotti, G. Suzzi, and A. Gianotti. 1999. Effect of high pressure homogenization on microbiol and chemico-physical characteristics of goat cheeses. J. Dairy Sci. 82:851-862. 
Hannon, J. A., M. G. Wilkinson, C. M. Delahunty, J. M. Wallace, P. A. Morrissey, and T. P. Beresford. 2003. Use of autolytic starter systems to accelerate the ripening of Cheddar cheese. Int. Dairy J. 13:313-323.

International Dairy Federation. 1991. Rheological and fracture properties of cheeses. IDF Bull. 268. IDF, Brussels, Belgium.

International Dairy Federation. 1993. Milk determination of nitrogen content. IDF standard no-20B. IDF, Brussels, Belgium.

Kanawija, S. K., K. N. Rao, S. Singh, and L. Sabikhi. 1993. Role of lactobacilli in cheese. A review. Indian J. Dairy Sci. 46:187-197.

Kang, O. J., L. P. Vezina, S. Laberge, and R. E. Simard. 1998. Some factors influencing the autolysis of Lactobacillus bulgaricus and Lactobacillus casei. J. Dairy Sci. 81:639-646.

Kebary, K. M. K., A. E. Khader, A. N. Zedan, and S. F. Mahmoud. 1996. Accelerated ripening of low fat Ras cheese by attenuated lactobacilli cells. Food. Res. Int. 29:705-713.

Kempler, G. M., and L. L. McKay. 1980. Improved medium for detection of citrate fermenting Streptococcus lactis subsp. diacetylactis. Appl. Environ. Microbiol. 4:926-927.

Kheadr, E. E., J. C. Vuillemard, and S. A. El Deeb. 2000. Accelerated Cheddar cheese ripening with encapsulated proteinases. Int. J. Food Sci. Technol. 35:483-495.

Kheadr, E. E., J. C. Vuillemard, and S. A. El Deeb. 2002. Acceleration of Cheddar cheese lipolysis by using liposome-entrapped lipases. J. Food Sci. 67:485-492.

Kheadr, E. E., J. C. Vuillemard, and S. A. El Deeb. 2003. Impact of liposome-encapsulated enzyme cocktails on Cheddar cheese ripening. Food Res. Int. 36:241-252.

Klein, N., and S. Lortal. 1999. Attenuated starters: An efficient means to influence cheese ripening. A review. Int. Dairy J. 9:751-762.

Kosikowski, F. V. 1982. Cheddar cheese. Pages 228-260 in Cheese and Fermented Milk Foods. 3rd ed. F. V. Kosikowski and Assoc., Brooktondale, NY.

Kuchroo, C. N., and P. F. Fox. 1982. Soluble nitrogen in Cheddar cheese: Comparison of extraction procedures. Milchwissenschaft 37:331-335.

Lau, K. Y., D. M. Barbano, and R. R. Rasmussen. 1991. influence of pasteurization of milk on protein breakdown in Cheddar cheese during aging. J. Dairy Sci. 74:727-740.

Law, B. A. 1990. Accelerated ripening of cheese. Proc. 24th Int. Dairy Congr., Montreal, Canada.

Lynch, C. M., P. L. H. McSweeney, P. F. Fox, T. M. Cogan, and F. D. Drinan. 1996. Manufacture of Cheddar cheese with and without adjunct lactobacilli under controlled microbiological conditions. Int. Dairy J. 6:851-867.

Madkor, S. A., M. El Soda, and P. S. Tong. 2000. Ripening of Cheddar cheese with added attenuated adjunct cultures of lactobacilli. J. Dairy Sci. 83:1684-1691.

Madkor, S. A., M. El Soda, and P. S. Tong. 1999. Evaluation of commercial adjuncts for use in cheese ripening. 2. Ripening aspects and flavor development in cheese curd slurries prepared with adjunct lactobacilli. Milchwissenschaft 54:133-137.

Martínez-Cuesta, M. C., C. Peláez, M. Juárez, and T. Requena. 1997. Autolysis of Lactococcus lactis ssp. lactis and Lactobacillus casei ssp. casei. cell lysis induced by a crude bacteriocin. Int. J. Food Microbiol. 38:125-131.
Martínez-Cuesta, M. C., P. Fernández de Palencia, T. Requena, and C. Peláez. 1998. Enhancement of proteolysis by Lactococcus lactis bacteriocin producer in a cheese model system. J. Agric. Food Chem. 46:3863-3867.

Martínez-Cuesta, M. C., J. Kok, E. Herranz, C. Peláez, T. Requena, and G. Buist. 2000. Requirement of autolytic activity for bacteriocin-induced lysis. Appl. Environ. Microbiol. 66:3174-3179.

Meghrous, J., C. Lacroix, M. Bouksaim, G. Lapointe, and R. E. Simard. 1997. Genetic and biochemical characterization of nisin Z produced by Lactococcus lactis subsp. lactis biovar. diacetylactis UL719. J. Appl. Microbiol. 83:133-138.

Midje, L. D., E. D. Bastian, H. A. Morris, F. B. Martin, T. Bridgeman, and Z. M. Vickers. 2000. Flavor enhancement of reduced fat Cheddar cheese using an integrated culturing system. J. Agric. Food Chem. 48:1630-1636.

Morgan, S., R. P. Ross, and C. Hill. 1997. Increasing starter cell lysis in Cheddar cheese using a bacteriocin-producing adjunct. J. Dairy Sci. 80:1-10.

Oommen, B. S., D. J. McMahon, C. J. Oberg, J. R. Broadbent, and M. Strickland. 2002. Proteolytic specificity of Lactobacillus delbrueckii subsp. bulgaricus influences functional properties of Mozzarella Cheese. J. Dairy Sci. 85:2750-2758.

Puchades, R., L. Lemieux, and R. E. Simard. 1989. Evolution of free amino acids during the ripening of Cheddar cheese containing added lactobacilli strains. J. Food Sci. 54:885-888 and 946.

Sallami, L. 2003. Étude de l'incorporation d'une souche de Lactobacillus delbruckii ssp. bulgaricus U212 haurtement autolytique sur l'accélèration de la maturation d'un fromage de type Cheddar. $\mathrm{Ph}$. D. diss. Université Laval, Canada.

Terzaghi, B. E., and W. E. Sandine. 1975. Improved medium for lactic streptococci and their bacteriophages. Appl. Environ. Microbiol. 29:807-813.

Trépanier, G., R. E. Simard, and B. H. Lee. 1991. Effect of added Lactobacilli on composition and texture of Cheddar cheese during accelerated maturation. J. Food Sci. 56:696-700.

Trépanier, G., M. El Aboudoi, B. H. Lee, and R. E. Simard. 1992. Accelerated maturation of cheddar cheese: Microbiology of cheese supplemented with Lactobacillus casei subsp. casei. J. Food Sci. $57: 345-347$

Valence, F., R. Richoux, A. Thierry, A. Palva, and S. Lortal. 1998. Autolysis of Lactobacillus helveticus and Propionibacterium freudenreichii in Swiss cheeses: First evidence by using species-specific lysis markers. J. Dairy Res. 65:609-620.

Valence, F., S. M. Deutsch, R. Richoux, V. Gagnaire, and S. Lortal. 2000. Autolysis and related proteolysis in Swiss cheese for two Lactobacillus helveticus strains. J. Dairy Res. 67:261-271.

Wilkinson, M. G., T. P. Guinee, and P. F. Fox. 1994. Factors which may influence the determination of autolysis of starter bacteria during Cheddar cheese ripening. Int. Dairy J. 4:141-160.

Wilkinson, M. G., T. P. Guinee, D. M. O'Callaghan, and P. F. Fox. 1995. Effect of cooking temperature on the autolysis of starter, Lactococcus lactis subsp. cremoris AM2, and the maturation of Cheddar cheese. Milchwissenschaft 50:376-380.

Wouters, J. T. M., E. H. E. Ayad, J. Hugenholtz, and G. Smit. 2002. Microbes from raw milk for fermented dairy products. Int. Dairy J. 12:91-109. 